\title{
THE RENAL EXCRETION OF CITRATE*
}

\author{
BY ARTHUR P. GROLLMAN, $\dagger$ HELEN C. HARRISON AND HAROLD E. HARRISON
}

(From the Department of Pediatrics, Johns Hopkins University School of Medicine, and the Pediatric Division, Baltimore City Hospitals, Baltimore, Md.)

(Submitted for publication December 27, 1960; accepted March 23, 1961)

Amberg and McClure (1) first identified citric acid as a normal excretory product in human urine. Oestberg (2) noted that citrate excretion increased greatly during metabolic alkalosis and decreased during states of acidosis and thus varied with urinary $\mathrm{pH}$. Other investigators $(3,4)$ demonstrated that factors other than urinary $\mathrm{pH}$ also altered the excretion of citric acid. Study of the metabolic pathways of citrate formation and utilization culminated in the classic paper of Krebs and Johnson (5) in which the tricarboxylic acid cycle was first postulated. Krebs included succinate, $l$-malate, and fumarate as participants in the "cycle." Orten and Smith (6) reported that the intravenous administration of these dicarboxylic acids increased the urinary excretion of citrate, and malonate was also shown to have the same effect. Krebs, Salvin and Johnson (7) extended these experiments, demonstrated that oxaloacetate increased citrate and $\alpha$-ketoglutarate output in urine, and suggested that malonic acid acted as a succinic dehydrogenase inhibitor rather than as a direct precursor of citric acid in the proposed cycle. No consideration was given to the renal clearance of citrate and the possibility of changes in tubular reabsorption, or of secretion, of this solute as a factor in altered urine citrate output, so that a greatly increased urinary excretion of citrate was accepted as prima facie evidence of increased endogenous production. However, the relative roles of filtration, tubular reabsorption, and secretion, together with the factors that influence them, must be properly evaluated before conclusions are drawn regarding changes in urine citrate output as evidences of its altered metabolism. Herrin and Lardinois (8) did make studies of citrate excretion in dogs with clearance tech-

* This work was supported by Grant A668 from the National Institutes of Health.

$\dagger$ Present address: National Institute of Arthritis and Metabolic Diseases, National Institutes of Health, Bethesda, Md. niques and noted marked elevation of citrate clearances after the administration of bicarbonate. Keyl and Lotspeich (9) measured citrate clearances in dogs after infusion of sodium citrate. These experiments suggested that citrate was filtered and reabsorbed and that there was no demonstrable $\mathrm{Tm}$ for citrate at the highest plasma concentrations of citrate tolerated by the dog. The renal excretion of malic acid, one of the dicarboxylic acids in the citric acid cycle has been investigated in detail by Vishwakarma and Lotspeich (10), who demonstrated net tubular secretion of this acid by the dog kidney when the animals were given citrate, succinate or $\alpha$-ketoglutarate. When $l$-malate was infused, on the other hand, there was net tubular reabsorption of malate with a definite $\mathrm{Tm}$.

The present experiments were undertaken to explore further the mechanisms of citric acid excretion in the dog by means of clearance techniques. The effects of metabolic alkalosis, acidosis, acetazolamide, and certain dicarboxylic acids of the tricarboxylic acid cycle on the renal excretion of citric acid have been tested. Part of this work has previously been reported in a preliminary abstract (11).

\section{METHODS}

Mongrel female dogs, weighing 10 to $20 \mathrm{~kg}$, were anesthetized with $20 \mathrm{mg}$ per $\mathrm{kg}$ of sodium pentobarbital and maintained under light anesthesia for the duration of the experiment. Simultaneous clearances of citrate and creatinine were determined by standard clearance methods (12) with serial clearance periods of 10 to $15 \mathrm{~min}$ utes each. Blood samples were taken from the femoral artery. Renal arteriovenous differences were obtained by inserting a cardiac catheter into the jugular vein and passing it through the vena cava into the right renal vein. Simultaneous blood samples were then taken from the renal vein and the femoral artery.

Creatinine was given as a priming dose of $500 \mathrm{mg}$ and added in sufficient concentration in the subsequent infusion solution to maintain a serum level of approximately $10 \mathrm{mg}$ per $100 \mathrm{ml}$. In the experiments investi- 
gating the effects of acidosis, alkalosis and acetazolamide on renal handling of citrate, a $0.05 \mathrm{M}$ solution of sodium citrate was slowly infused into a peripheral vein, the rate being regulated at $3 \mathrm{ml}$ per minute by a peristaltic action infusion pump. Arterial blood samples were taken every 10 minutes and the citrate clearances determined while the plasma citrate was progressively raised to approximately $20 \mathrm{mg}$ per $100 \mathrm{ml}$. Metabolic alkalosis and acidosis were effected by intragastric administration of sodium bicarbonate or ammonium chloride solutions during the 24 hour period prior to the experiment.

In the experiments testing the effect of acetazolamide, doses of $50 \mathrm{mg}$ per $\mathrm{kg}$ each were given orally 24,12 , and 1 hour before the experiment. In certain of these studies the effect of acetazolamide and concomitant metabolic alkalosis was determined. It was necessary to give two to three times the alkalinizing dose of bicarbonate used in control animals to achieve the same degree of elevation of plasma bicarbonate levels in the animals receiving acetazolamide as in the controls.

Experiments were also performed to test the effect of malic, succinic, and malonic acids on the renal clearances of citrate. These dicarboxylic acids were given by priming the animals with solutions of the sodium salts, supplying 3 mmoles per $\mathrm{kg}$ body weight. This was followed by a constant infusion of the sodium salts as a $0.05 \mathrm{M}$ solution at a rate of $3 \mathrm{ml}$ per minute.

Creatinine was measured by the picric acid method as modified by Brod and Sirota (13), citrate as described by Natelson, Pincus and Lugovoy (14), $\mathrm{CO}_{2}$ content by the manometric technique of Peters and Van Slyke (15); and $\mathrm{pH}$ with the Beckman glass electrode.

\section{RESULTS}

Effect of metabolic alkalosis and acidosis. Figure 1 illustrates the clearance of citrate with rising plasma citrate concentrations during states of normal ( 25 to $29 \mathrm{mEq}$ per L), elevated ( 40 to 45 $\mathrm{mEq}$ per $\mathrm{L}$ ) and reduced ( 15 to $19 \mathrm{mEq}$ per $\mathrm{L}$ ) concentrations of serum bicarbonate. In the experiments in which serum bicarbonate concentrations were in the physiological range, citrate was not excreted in the urine in the periods before the intravenous injection of this ion and did not appear until the concentration of citrate in plasma reached 6 to $8 \mathrm{mg}$ per $100 \mathrm{ml}$. In the metabolic acidosis experiments citrate was not found in the urine until the plasma level was raised to $13 \mathrm{mg}$ per $100 \mathrm{ml}$, but after induction of metabolic alkalosis, citrate was excreted even at normal plasma concentrations of 2 to $4 \mathrm{mg}$ per $100 \mathrm{ml}$. The citrate to creatinine clearance ratios were compared in the normal, acidotic and alkalotic states during periods when the plasma citrate concen-

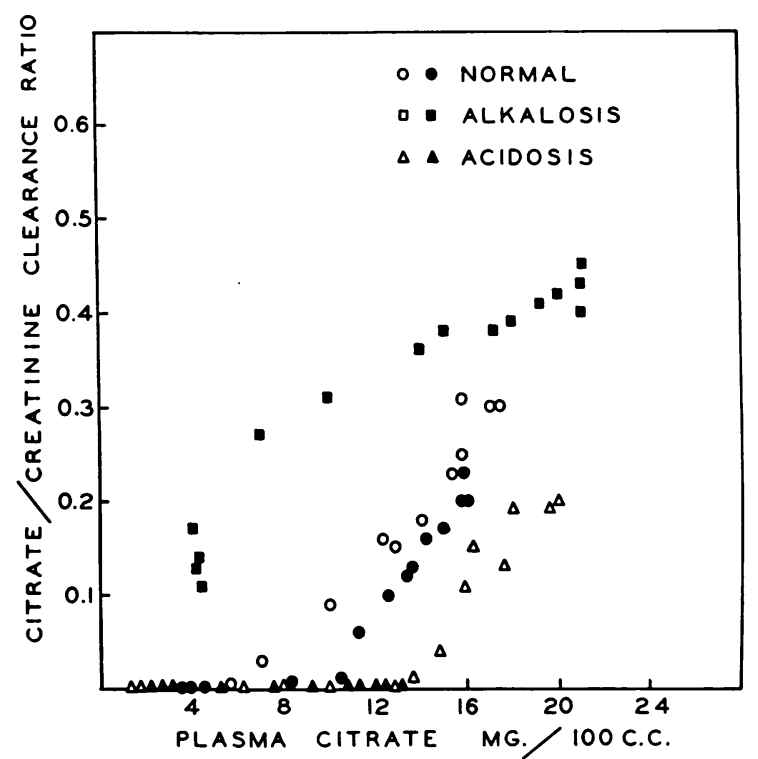

Fig. 1. The effect of metabolic alkalosis and ACIDOSIS ON THE CITRATE TO CREATININE CLEARANCE RAtio at various SERUM CITRATE CONCENTRATIONS. Solid symbols indicate results of experiments in one animal; hollow symbols the data from experiments in a second dog.

tration had been raised to the same level $(18 \mathrm{mg}$ per $100 \mathrm{ml}$ ). The ratios were approximately 0.3 in the normal state, 0.2 during acidosis and 0.4 during alkalosis. The rate of urine flow during the infusion of citrate was in the same range in the experiments in the bicarbonate-loaded dogs as in the control studies (between 4 to $8 \mathrm{ml}$ per minute). The effect of bicarbonate-induced alkalosis on citrate clearance could not be correlated with urine volume. In one of the acidosis experiments, urine flow was reduced to less than 1 $\mathrm{ml}$ per minute but in the second was maintained at over $4 \mathrm{ml}$ per minute. No evidence of a Tm for citrate was seen as the plasma citrate levels were raised to approximately $20 \mathrm{mg}$ per $100 \mathrm{ml}$. This concurs with the data of Keyl and Lotspeich (9), who found no $\mathrm{Tm}$ for citrate at the highest citrate loads tolerated by the dog.

Effect of acetazolamide. The clearance of citrate at normal and at elevated plasma concentrations of citrate is illustrated in Figure 2 in a dog given bicarbonate alone (serum $\mathrm{HCO}_{3}, 40$ to $43 \mathrm{mEq}$ per L), acetazolamide (serum $\mathrm{HCO}_{3}, 17$ to $20 \mathrm{mEq}$ per L) and both bicarbonate and acetazolamide (serum $\mathrm{HCO}_{3}, 31$ to $35 \mathrm{mEq}$ per $\mathrm{L}$ ). 


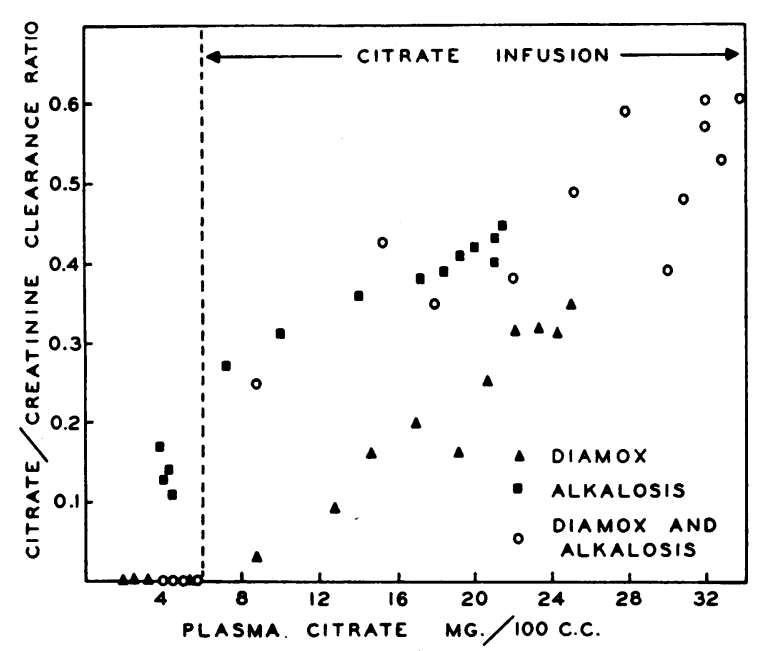

Fig. 2. THE EFFEct OF ACETAZOLAMIDE WITH AND WITHOUT METABOLIC ALKALOSIS ON THE CITRATE TO CREATININE CLEARANCE RATIO AT NORMAL AND ELEVATED SERUM CITRATE CONCENTRATIONS. These data represent results of repeated experiments in a single dog.

After administration of acetazolamide to the alkalotic dog, citrate was not excreted at the normal plasma levels of 2 to $4 \mathrm{mg}$ per $100 \mathrm{ml}$, indicating complete tubular reabsorption of this ion despite the alkalosis. Citrate clearances were compared at fasting and at increased plasma citrate concentrations in three dogs during metabolic alkalosis with and without acetazolamide administration.
The results are shown in Table I. Although at normal plasma citrate concentrations no citrate was excreted during the acetazolamide periods, after citrate infusion tubular reabsorption of citrate was no longer complete. The clearances of citrate were less in the acetazolamide-treated dogs at comparable plasma concentrations, but in two of the three dogs the creatinine clearances were decreased after the vigorous treatment with acetazolamide.

Effect of malate, succinate, and malonate on citrate clearance. The effect of sodium $l$-malate upon the excretion of citrate is shown in Figure 3. As $l$-malate was infused, the clearance ratio of citrate to creatinine increased rapidly, and the citrate clearances became equal to the creatinine clearances within the limits of error of the methods. In this experiment there was no change in serum citrate levels, which remained at the fasting level between 2.1 and $2.6 \mathrm{mg}$ per $100 \mathrm{ml}$, and the serum bicarbonate concentration was $28 \mathrm{mEq}$ per $L$. The experiment was repeated under conditions of alkalosis with a serum bicarbonate concentration of 40 to $44 \mathrm{mEq}$ per $\mathrm{L}$ and again a citrate to creatinine clearance ratio of 1 was not exceeded. When sodium citrate was added to the infusion fluid along with the malate, the citrate clearance decreased so that the citrate to creatinine

TABLE I

The effect of acetazolamide on renal clearance of citrate in dogs with metabolic alkalosis, before and after loading with sodium citrate

\begin{tabular}{|c|c|c|c|c|c|c|c|c|c|}
\hline \multirow[b]{3}{*}{ Dog } & \multirow{3}{*}{$\begin{array}{c}\text { Type of } \\
\text { experiment }\end{array}$} & \multicolumn{4}{|c|}{ Control period } & \multicolumn{4}{|c|}{ High citrate period } \\
\hline & & \multicolumn{2}{|c|}{ Serum } & \multicolumn{2}{|c|}{ Clearances* } & \multicolumn{2}{|c|}{ Serum } & \multicolumn{2}{|c|}{ Clearances } \\
\hline & & Citrate & $\mathrm{HCO}_{3}$ & Creat. & Citrate & Citrate & $\mathrm{HCO}_{3}$ & Creat. & Citrate \\
\hline & & $\mathrm{mg} / 100 \mathrm{ml}$ & $m E q / L$ & \multicolumn{2}{|c|}{$\mathrm{ml} / \mathrm{min}$} & $m g / 100 \mathrm{ml}$ & $m E q / L$ & \multicolumn{2}{|c|}{$\mathrm{ml} / \mathrm{min}$} \\
\hline A & $\begin{array}{c}\mathrm{NaHCO}_{3} \\
\mathrm{NaHCO}_{3} \\
+ \\
\text { acetazol. }\end{array}$ & $\begin{array}{l}4.2 \\
5.5\end{array}$ & $\begin{array}{l}41 \\
35\end{array}$ & $\begin{array}{l}48 \\
23\end{array}$ & $\begin{array}{l}6.1 \\
0\end{array}$ & $\begin{array}{l}13 \\
15\end{array}$ & $\begin{array}{l}41 \\
35\end{array}$ & $\begin{array}{l}55 \\
28\end{array}$ & $\begin{array}{l}18 \\
11\end{array}$ \\
\hline B & $\begin{array}{c}\mathrm{NaHCO}_{3} \\
\mathrm{NaHCO}_{3} \\
+ \\
\text { acetazol. }\end{array}$ & $\begin{array}{l}3.9 \\
5.2\end{array}$ & $\begin{array}{l}31 \\
31\end{array}$ & $\begin{array}{l}37 \\
31\end{array}$ & $\begin{array}{l}8.3 \\
0\end{array}$ & $\begin{array}{l}11 \dagger \\
11 \dagger\end{array}$ & $\begin{array}{l}30 \\
31\end{array}$ & $\begin{array}{l}42 \\
35\end{array}$ & $\begin{array}{l}38 \dagger \\
16 \dagger\end{array}$ \\
\hline $\mathrm{C}$ & $\begin{array}{c}\mathrm{NaHCO}_{3} \\
\mathrm{NaHCO}_{3} \\
+ \\
\text { acetazol. }\end{array}$ & $\begin{array}{l}3.8 \\
4.4\end{array}$ & $\begin{array}{l}40 \\
39\end{array}$ & $\begin{array}{l}57 \\
56\end{array}$ & $\begin{array}{l}6.4 \\
0\end{array}$ & $\begin{array}{r}10 \dagger \\
8 \dagger\end{array}$ & $\begin{array}{l}40 \\
39\end{array}$ & $\begin{array}{l}48 \\
55\end{array}$ & $\begin{array}{l}9 \dagger \\
2 \dagger\end{array}$ \\
\hline
\end{tabular}

* Results are expressed as an average of three collection periods.

† Figures listed represent the results of the final clearance period The serum citrate values are the maximum achieved in these experiments. In the results given on Dog A clearance periods were selected in which the serum citrate concentrations were approximately the same in the $\mathrm{NaHCO}_{3}$ and acetazolamide experiments. 
TABLE II

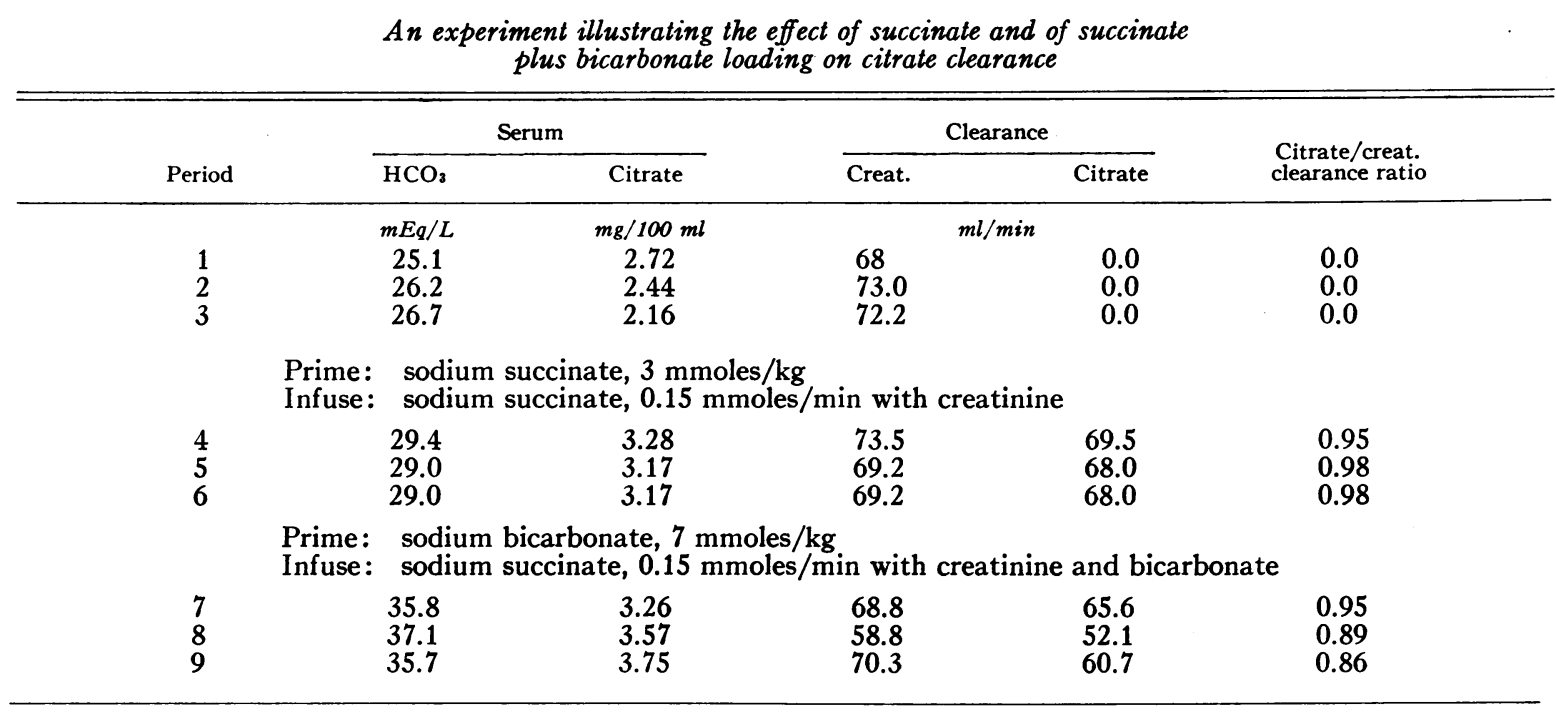

clearance ratio was less than 1 . Injection of succinate produced an effect similar to that of malate, the citrate to creatinine clearance ratio again approaching unity. When, in addition, sodium bicarbonate was infused, the serum bicarbonate was elevated from 26 to $36 \mathrm{mEq}$ per $100 \mathrm{ml}$ without increasing the citrate clearance above the filtration rate (Table II). Injection of the sodium salt of malonic acid, which acts in vitro as a succinic acid dehydrogenase inhibitor, did not alter the effect of succinate on the citrate clearance. In the studies of malate excretion by Vishwakarma and Lotspeich (10), the tubular secretion of malate after injection of succinate was blocked by malonate.

The effect of malonic acid alone is seen in Table III. Its behavior was similar to that of malate and succinate in that it, too, increased the citrate clearance until it was approximately equal to the glomerular filtration rate.

Effect of malate on utilization of citrate. By simultaneous measurement of renal clearances of citrate and creatinine and of renal arteriovenous differences of these solutes, the utilization of citrate may be calculated. Representative data are shown in Table IV. Renal plasma flow was calculated by the formula of Wolf (16) from the renal arteriovenous difference of creatinine and the creatinine clearance. After three control periods $l$-malate was infused, and citrate utilization calculated during the control periods and after tubular reabsorption of citrate was inhibited by malate. Utilization of citrate was strikingly decreased after malate injection, averaging about 10 per cent of control values. The citrate that continued to be utilized after malate infusion approximated, within the limit of experimental error, the estimated excess of utilized over filtered citrate during the control period.

\section{DISCUSSION}

Oestberg (2) concluded from his early experiments that urinary $\mathrm{pH}$ was the most important factor governing citrate excretion. It was later shown, however, that the variations in citraturia

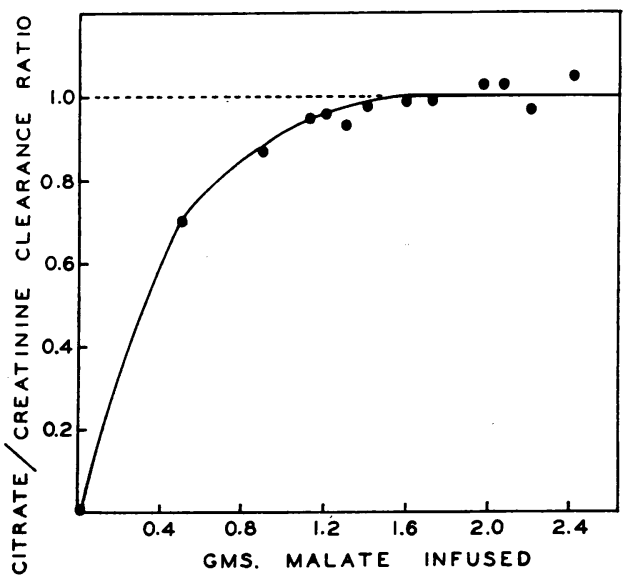

Fig. 3. Experiment Illustrating the efFect of MALATE INFUSION ON THE CLEARANCE OF CITRATE. 
TABLE III

An experiment illustrating the effect of malonate-on citrate clearance

\begin{tabular}{|c|c|c|c|c|c|}
\hline \multirow[b]{2}{*}{ Period } & \multicolumn{2}{|c|}{ Serum } & \multicolumn{2}{|c|}{ Clearance } & \multirow{2}{*}{$\begin{array}{l}\text { Citrate/creat. } \\
\text { clearance ratio }\end{array}$} \\
\hline & $\mathrm{HCO}_{3}$ & Citrate & Creat. & $\overline{\text { Citrate }}$ & \\
\hline \multirow{5}{*}{$\begin{array}{l}1 \\
2 \\
3\end{array}$} & $m E q / L$ & $\mathrm{mg} / 100 \mathrm{ml}$ & \multicolumn{2}{|c|}{$m l / \min$} & \\
\hline & 25.1 & 3.41 & 40.5 & 0.0 & 0.0 \\
\hline & 23.7 & 3.18 & 45.0 & 0.0 & 0.0 \\
\hline & 24.7 & 3.25 & 42.3 & 0.0 & 0.0 \\
\hline & $\begin{array}{l}\text { Prime: } \\
\text { Infuse: }\end{array}$ & \multicolumn{4}{|c|}{$\begin{array}{l}\text { sodium malonate, } 3 \mathrm{mmoles} / \mathrm{kg} \\
\text { sodium malonate, } 0.15 \mathrm{mmoles} / \mathrm{min} \text { with creatinine }\end{array}$} \\
\hline $\begin{array}{l}4 \\
5 \\
6\end{array}$ & $\begin{array}{l}25.0 \\
25.5 \\
25.8\end{array}$ & $\begin{array}{l}2.60 \\
2.78 \\
2.78\end{array}$ & $\begin{array}{l}30.2 \\
30.1 \\
31.8\end{array}$ & $\begin{array}{l}27.8 \\
29.4 \\
29.9\end{array}$ & $\begin{array}{l}0.92 \\
0.98 \\
0.94\end{array}$ \\
\hline
\end{tabular}

observed following the intake of food could not be explained solely on the basis of urinary acidbase relationships. Recent evidence concerning the effect of potassium on urine citrate excretion has been presented by Cooke and co-workers (17), who noted in rats a large increase in the output of citrate and also of $\alpha$-ketoglutarate following potassium administration to potassium-deficient animals with hypochloremic alkalosis. This occurred in experiments in which the urine $\mathrm{pH}$ was unchanged. Evans, MacIntyre, MacPherson and Milne (18) have presented similar data in a potassium-deficient man. Potassium chloride administration resulted in an increased excretion of citrate and $\alpha$-ketoglutarate in urine, although the urine $\mathrm{pH}$ dropped. The dissociation of urine $\mathrm{pH}$ and citrate excretion is further shown by the effect of acetazolamide, which decreases citrate excretion in rats and man although urine $\mathrm{pH}$ is increased $(19,20)$. In the present experiments, when the urine is made alkaline by bicarbonate feeding in the absence of acetazolamide, an increased citrate excretion results; but in experiments in which acetazolamide and bicarbonate are given simultaneously, there is complete tubular reabsorption of citrate at fasting serum concentrations in the face of a markedly elevated urinary $\mathrm{pH}$ and an increased serum $\mathrm{pH}$. This suggests that tubular reabsorption of citrate is influenced by acetazolamide by a mechanism not dependent upon alteration of $\mathrm{pH}$ either of urine or of extracellular fluid. Evans and colleagues (18) and Milne, Scribner and Crawford (21) have developed the hypothesis that renal tubular reabsorption of citrate is controlled by the $\mathrm{pH}$ within renal tubule cells rather than by urine $\mathrm{pH}$. A reduced intracellular $\mathrm{pH}$ in potassium-deficient states could then explain the diminished citrate clearance which has been found. The alterations of $\mathrm{pH}$ in renal tubule cells are only conjectural

TABLE IV

An experiment illustrating the effect of malate on citrate utilization by the kidney

\begin{tabular}{|c|c|c|c|c|c|c|c|c|}
\hline \multirow[b]{2}{*}{ Period } & \multirow{2}{*}{$\begin{array}{c}\text { Renal } \\
\text { plasma } \\
\text { flow }\end{array}$} & \multirow{2}{*}{$\begin{array}{l}\text { Creatinine } \\
\text { clearance }\end{array}$} & \multirow{2}{*}{$\begin{array}{l}\text { Citrate/creat. } \\
\text { clearance ratio }\end{array}$} & \multicolumn{5}{|c|}{ Citrate } \\
\hline & & & & Plasma & Filtered & Excreted & Reabsorbed & Utilized \\
\hline \multirow{3}{*}{$\begin{array}{l}1 \\
2 \\
3\end{array}$} & $\mathrm{ml} / \min$ & $\mathrm{ml} / \mathrm{min}$ & & $\mathrm{mg} / 100 \mathrm{ml}$ & & & & \\
\hline & $\begin{array}{l}250 \\
286 \\
257\end{array}$ & $\begin{array}{l}80.2 \\
84.7 \\
83.1\end{array}$ & $\begin{array}{l}0.0 \\
0.0 \\
0.0\end{array}$ & $\begin{array}{l}2.66 \\
2.62 \\
2.29\end{array}$ & $\begin{array}{l}2.13 \\
2.22 \\
1.90\end{array}$ & $\begin{array}{l}\mathbf{0} \\
\mathbf{0} \\
\mathbf{0}\end{array}$ & $\begin{array}{l}2.13 \\
2.22 \\
1.90\end{array}$ & $\begin{array}{l}2.40 \\
3.80 \\
2.24\end{array}$ \\
\hline & & $\begin{array}{l}\text { Prime: } \\
\text { Infuse: }\end{array}$ & \multicolumn{4}{|c|}{$\begin{array}{l}\text { sodium malate, } 2 \mathrm{mmoles} / \mathrm{kg} \\
\text { sodium malate, } 0.15 \mathrm{mmoles} / \mathrm{min} \text { with creatinine }\end{array}$} & & \\
\hline $\begin{array}{l}4 \\
5 \\
6\end{array}$ & $\begin{array}{l}358 \\
314 \\
368\end{array}$ & $\begin{array}{l}82.6 \\
79.5 \\
82.3\end{array}$ & $\begin{array}{l}1.03 \\
1.04 \\
1.10\end{array}$ & $\begin{array}{l}2.66 \\
2.72 \\
2.66\end{array}$ & $\begin{array}{l}2.19 \\
2.16 \\
2.19\end{array}$ & $\begin{array}{l}2.27 \\
2.25 \\
2.43^{*}\end{array}$ & $\begin{array}{l}\mathbf{0} \\
\mathbf{0} \\
\mathbf{0}\end{array}$ & $\begin{array}{l}0.27 \\
0.77 \\
0.01\end{array}$ \\
\hline
\end{tabular}

* During this clearance period citrate excreted exceeded that calculated to be filtered by 10 per cent. This single datum would be compatible with tubular secretion but is probably within the range of experimental error. 
so that this hypothesis has not been subjected to any real test. The $\mathrm{pH}$ of the renal tubule cell in the alkalotic dog given acetazolamide is unknown.

Vishwakarma and Lotspeich (10) have clearly shown that in the dog, malic acid is secreted by the renal tubules after infusion of citrate, $\alpha$-ketoglutarate, and succinate. No evidence of tubular secretion of citrate is seen in the data presented here. The citrate clearance becomes approximately equal to, but not greater than, the creatinine clearance when the structurally related organic acids-succinate, malate, and malonateare infused. Increasing the serum and urinary $\mathrm{pH}$ by administration of sodium bicarbonate along with these dicarboxylic acids does not affect this maximal clearance in any way. The combination of metabolic alkalosis and elevation of plasma citrate concentration also does not result in citrate clearances greater than the simultaneously measured glomerular filtration rate.

Renal clearance measurements can demonstrate tubular secretion of a solute only if addition of the solute to tubular urine is greater than any reabsorption that may occur. Clearance experiments cannot of themselves, therefore, exclude bidirectional transfer of solute in the renal tubule if reabsorption is equal to, or greater than, the transfer of solute from cell to tubular urine. It is conceivable, then, that fluctuations in citrate excretion under the experimental conditions imposed may result from alterations in the addition of citrate from the cells as well as in the tubular reabsorption of citrate. However, the probability seems greater that the important variable is in tubular reabsorption of citrate. Certainly, none of the procedures pushed citrate excretion beyond the estimated amounts filtered through the glomeruli. The essential coincidence of the citrate and creatinine clearances in a number of experiments in which dicarboxylic acids were injected suggests virtually complete inhibition of tubular reabsorption of citrate by malate, succinate, and malonate which is overcome when the filtered citrate is increased by injection of sodium citrate. This latter phenomenon suggests a competitive mechanism.

Serum citrate levels increase little if at all after the injection of malate or succinate despite the manyfold increase in urine excretion. This also suggests that these dicarboxylic acids increase citrate clearances by competition with this ion for a tubular reabsorptive mechanism rather than by increasing cellular production of citrate through the tricarboxylic acid cycle. Furthermore, the effect of succinate is not reversed by addition of malonate but rather, malonate itself has an effect similar to that of malate and succinate.

Finally, we have confirmed the observation of Martensson (22) and Herndon and Freeman (23) that the amount of citrate removed by the kidney is somewhat greater than that calculated to be filtered. This indicates that the citric acid metabolized by the kidneys is not derived solely from that taken up from the tubular lumen. However, after the administration of malate, utilization is decreased by 80 to 90 per cent. There are two possible interpretations of this phenomenon. One is that an increase of malate within the cell inhibits citrate utilization, and the consequent increase in intracellular citrate concentration blocks tubular reabsorption of citrate. An alternative and more probable explanation is that the greatest part of the citrate utilized by the kidneys is obtained from the luminal side of the renal tubular cell by a process of reabsorption which can be competitively inhibited by malate, succinate, or malonate. A small but definite percentage probably diffuses into the tubule cell from the peritubular space by a mechanism that is not affected by the presence of other tricarboxylic acid cycle substrates.

\section{SUMMARY}

The effects of acidosis, alkalosis, acetazolamide, and certain organic acids of the tricarboxylic acid cycle on the renal excretion of citric acid in the dog have been investigated by means of standard clearance techniques. Citrate clearances are increased by alkalosis and diminished by acidosis. Tubular reabsorption of citrate is complete at normal serum concentrations in alkalotic, acetazolamide-treated dogs, suggesting that acetazolamide increases the tubular reabsorption of citrate at ordinary filtered loads by a mechanism unrelated to the $\mathrm{pH}$ of urine or of plasma.

When plasma citrate concentrations are raised to eight to ten times normal values, the citrate clearances are still less than the glomerular filtration rate even though metabolic alkalosis is super- 
imposed in an effort to inhibit tubular reabsorption of citrate. The citrate clearances become equal to the creatinine clearances after infusions of sodium $l$-malate at normal or increased plasma bicarbonate concentrations. Sodium succinate also increases citrate clearances so that they are equal to the filtration rate, and this effect is not influenced by addition of the succinic dehydrogenase inhibitor, malonic acid. During these experiments the concentration of citrate in the plasma remains in the normal range. The intravenous injection of sodium citrate reverses the effect of malate on tubular reabsorption of citrate. The renal utilization of this ion as calculated from renal arteriovenous differences and simultaneous urinary clearance measurements is strikingly inhibited by the injection of $l$-malate.

These data are consistent with a renal mechanism of citrate excretion involving filtration and reabsorption without tubular secretion. The reabsorption and subsequent utilization of filtered citrate by the tubule cell appear to be competitively inhibited by the tricarboxylic acid cycle substrates -malate and succinate-and also by malonate.

\section{ACKNOWLEDGMENTS}

The authors wish to express their thanks for the valuable technical assistance of Miss Eleanor Baumgart.

\section{REFERENCES}

1. Amberg, S., and McClure, W. B. Occurrence of citric acid in urine. Amer. J. Physiol. 1917, 44, 453.

2. Oestberg, O. Studien über die Zitronensäureausscheidung der Menschenniere in normalen und pathologischen Zuständen. Skand. Arch. Physiol. 1931, 62, 81.

3. Kuyper, A. C., and Mattill, H. A. Some aspects of citric acid metabolism. J. biol. Chem. 1933, 103, 51.

4. Boothby, W. M., and Adams, M. The occurrence of citric acid in urine and body fluids. Amer. J. Physiol. 1934, 107, 471.

5. Krebs, H. A., and Johnson, W. A. The role of citric acid in intermediate metabolism in animal tissues. Enzymologia 1937, 4, 148.

6. Orten, J. M., and Smith, A. H. A study of certain metabolites and related compounds as precursors of endogenous citric acid. J. biol. Chem. 1937, 117, 555.
7. Krebs, H. A., Salvin, E., and Johnson, W. A. The formation of citric and $\alpha$-ketoglutaric acids in the mammalian body. Biochem. J. 1938, 38, 113.

8. Herrin, R. C., and Lardinois, C. C. Renal clearance of citric acid in the dog. Proc. Soc. exp. Biol. (N. Y.) 1958, 97, 294.

9. Keyl, M. J., and Lotspeich, W. D., cited in Lotspeich, W. D. Metabolic Aspects of Renal Function. Springfield, Ill., C. C Thomas, 1959.

10. Vishwakarma, P., and Lotspeich, W. D. The excretion of $l$-malic acid in relation to the tricarboxylic acid cycle in the kidney. J. clin. Invest. 1959, 38, 414.

11. Grollman, A. P. Renal clearance of citric acid in the dog (abstract). Bull. Johns Hopk. Hosp. 1959, 105, 89.

12. Smith, H. W. Principles of Renal Physiology. New York, Oxford Univ. Press, 1956, p. 196.

13. Brod, J., and Sirota, J. H. The renal clearance of endogenous "creatinine" in man. J. clin. Invest. 1948, 27, 645.

14. Natelson, S., Pincus, J. B., and Lugovoy, J. K. Microestimation of citric acid; a new colorimetric reaction for pentabromoacetone. J. biol. Chem. 1948, 175, 745.

15. Peters, J. P., and Van Slyke, D. D. Quantitative Clinical Chemistry, vol. 2, Methods. Baltimore, Williams \& Wilkins, 1932, p. 283.

16. Wolf, A. V. Total renal blood flow at any urine flow or extraction fraction (abstract). Amer. J. Physiol. 1941, 133, p. 496.

17. Cooke, R. E., Segar, W. E., Reed, C., Etzwiler, D. D., Vita, M., Brusilow, S., and Darrow, D. C. The role of potassium in the prevention of alkalosis. Amer. J. Med. 1954, 17, 180.

18. Evans, B. M., MacIntyre, I., MacPherson, C. R., and Milne, M. D. Alkalosis in sodium and potassium depletion (with especial reference to organic acid excretion). Clin. Sci. 1957, 16, 53.

19. Harrison, H. E., and Harrison, H. C. Inhibition of urine citrate excretion and the production of renal calcinosis in the rat by acetazoleamide (Diamox) administration. J. clin. Invest. 1955, 34, 1662.

20. Gordon, E. E., and Sheps, S. G. Effect of acetazolamide on citrate excretion and formation of renal calculi. New Engl. J. Med. 1957, 256, 1215.

21. Milne, M. D., Scribner, B. H., and Crawford, M. A. Non-ionic diffusion and the excretion of weak acids and bases. Amer. J. Med. 1958, 24, 709.

22. Martensson, J. On the citric acid metabolism in mammals. Acta physiol. scand. 1940, 1, suppl. 2, pp. $1-96$.

23. Herndon, R. F., and Freeman, S. Renal citric acid utilization in the dog. Amer. J. Physiol. 1958, 192, 369. 